\title{
EDUCATION BACKGROUNDS OF TV WEATHERCASTERS
}

Thomas A. Green Jr., Carl J. Schreck III, Nathan S. Johnson, and Sonya Stevens Heath

About two-thirds of weathercasters have a traditional meteorology degree, while one-fifth have a broadcast degree or certification from Mississippi State University.

W hen news broadcasts first started including weather forecasts in the 1940 s, many of the people delivering the weather did not have any meteorology training (Henson 2010). Over the years, more weathercasters came to their jobs with a degree in meteorology. More recently, the field of television (TV) meteorology has been revolutionized again with the advent of online broadcast degrees and certificates from Mississippi State University (MSU). The meteorology programs at The Pennsylvania State University, Florida State University, and the University of Oklahoma are arguably the largest in our field. When it comes to

AfFiliations: Green-National Weather Service Pittsburgh, Moon Township, Pennsylvania; SCHRECK-North Carolina Institute for Climate Studies, North Carolina State University, Asheville, North Carolina; JoHnson- NBCUniversal Owned Television Stations, New York, New York, and Department of Marine, Earth, and Atmospheric Sciences, North Carolina State University, Raleigh, North Carolina; SteVEns HeATH-WCIV-TV, Charleston, South Carolina

CORRESPONDING AUTHOR: Thomas Green,

tom.green@noaa.gov

The abstract for this article can be found in this issue, following the table of contents.

DOI:10.1175/BAMS-D-17-0047.I

In final form 29 July 2018

(C)2019 American Meteorological Society

For information regarding reuse of this content and general copyright

information, consult the AMS Copyright Policy. broadcast meteorology, however, MSU's role cannot be overlooked. According to the university's Department of Geoscience's website, more than 350 students have enrolled in its program through distance education (http://distance.msstate.edu/geosciences /bomp/). Many of these students pursue MSU's degrees and certifications in broadcast meteorology. These programs are unique in that they do not require the advanced calculus and dynamics required by most guidelines for meteorological degrees. These weathercasters clearly have more knowledge of the science than someone with no formal meteorology training, yet they probably also have less than someone with a traditional degree. This study seeks to quantify what fraction of on-air weathercasters have a traditional degree in meteorology, a broadcast degree or certification from MSU, or no meteorological degree/certification.

This study follows in the vein of other recent BAMS articles that examined trends in both the workforces and higher education of our field. Knox (2008) discussed whether the production of meteorologists with bachelor degrees by universities was outstripping the job market's demand, while MacPhee and Canetto (2014) illustrated the gender disparities among faculty in atmospheric science. A few other recent studies of weathercasters tangentially examined their education backgrounds within larger discussions of the occupation. For example, Lazalier (1982) examined similarities and differences among television station weather departments. He surveyed 74 stations $(62 \%$ 
response rate) from the top 40 television markets and found that $52 \%$ of their weathercasters had a meteorology degree. Similarly, both Wilson (2008) and Maibach et al. $(2017 \mathrm{a}, \mathrm{b})$ performed voluntary surveys of weathercasters to learn their attitudes toward communicating climate science. The respondent's level of meteorological training was among the survey questions. Wilson (2008) had 217 respondents with a response rate of $48.8 \%$. He found that $54 \%$ of weathercasters had their highest degrees in meteorology, while $23 \%$ of weathercasters majored in journalism/mass communications. Maibach et al. (2017a,b) and other recent surveys by their research group have received 463-646 respondents at a rate of $22 \%-32 \%$. Maibach et al. (2017a) report that $65 \%$ of weathercasters have a bachelor's degree in meteorology, 9\% have a master's degree in meteorology, and $19 \%$ have a certificate in meteorology.

Cranford (2018) recently used the biographical sketches from television station websites to examine gender differences among weathercasters. These profiles are almost universally available, allowing her to analyze 2,040 weathercasters from all 210 television markets. While gender was her primary focus, education background was again among the variables collected with an effective response rate of $88 \%$. She found $57 \%$ of all weathercasters held meteorology degrees and $15 \%$ had meteorology certificates.

The current study uses a similar methodology to that of Cranford (2018). However, our focus is explicitly on the number of weathercasters with 4-yr bachelor's degrees and the prevalence of MSU broadcast degrees and certifications. We supplement the station biographies with LinkedIn profiles where available. By focusing on five subsets of television markets, we compiled education backgrounds on 421 meteorologists with the equivalent of a $94 \%$ response rate. Our specific focus on education backgrounds allows us to break down these responses by factors not examined in previous studies, such as region, market size, and station ownership. Our hypothesis was that higher levels of education will be found in larger markets and in regions with more active weather. The results will show that while more active regions like the southern and eastern U.S. regions do attract more skilled weathercasters, larger markets do not.

Our emphasis on MSU is not because it offers distance education or its concentration on broadcast meteorology. Rather, MSU's broadcast meteorology degree and certification programs do not require the advanced calculus and dynamics coursework required by the World Meteorological Organization, the National Weather Service, and perhaps most relevant to this audience, the American Meteorological Society (AMS) Certified Broadcast Meteorologist (CBM) program. We make no judgment on how that impacts their on-air presentation or their effectiveness as weathercasters, but we note this is a key difference between the new CBM and the previous AMS Seal of Approval. Neither Cranford (2018) nor Maibach et al. $(2017 \mathrm{a}, \mathrm{b})$ made this distinction, making our paper a valuable new contribution.

METHODOLOGY. Similar to Cranford (2018), the primary basis for determining a weathercaster's education background was to view his or her biography on the television station's website. All data were collected between September 2016 and February 2017. We assumed that a public-facing biography would include any and all related education to establish credibility. For the small percentage of weathercasters who did not list any undergraduate education, their LinkedIn profiles, if available, were viewed to determine their education backgrounds. In a few remaining cases, the weathercaster's Facebook and Twitter profiles, if available, were also viewed for information. The 27 weathercasters whose fields of education could not be determined were removed from the sample.

Based on these publicly available data, weathercasters were categorized into one of four groups:

1) Degreed: A traditional undergraduate or graduate degree in meteorology, including the MSU Professional Meteorology degrees

2) MSU Broadcast: A broadcast meteorology degree or certification from MSU

3) Minor/Military: A minor in meteorology or military experience

4) Other: No mention of completed meteorological education or a mention of having completed some meteorological coursework

These groupings are broadly similar to those of Cranford (2018) with a few key differences. Both studies separate weathercasters with the MSU Broadcast Certificate from those with a degree; however, we take a different approach to MSU's degrees. MSU offers two distinct concentrations within its master's and bachelor's degrees. One concentration is the Professional Meteorology Concentration, which meets the guidelines set forth by the World Meteorological Organization (2015), the U.S. federal civil service requirements (www.opm.gov/policy -data-oversight/classification-qualifications/general 
-schedule-qualification-standards/I300/meteorology -series-1340/), and the AMS Certified Broadcast Meteorologist designation (www.ametsoc.org/ams /index.cfm/education-careers/ams-professional -certification-programs/certified-broadcast -meteorologist-program-cbm/). Its requirements are broadly similar to those at other major universities, so it fits logically in the Degreed category.

The other concentration is the Broadcast Meteorology Concentration, which we believe is unique to MSU. It lacks some of the math and physics requirements of the guidelines listed above, including Calculus III, Differential Equations, Calculus-Based Physics, and Dynamics II, in favor of broadcast and communications courses and practicums (www.geosciences.msstate.edu/undergraduate /meteorology/). Cranford (2018) treated both as degrees, but we believed it important to distinguish the differing requirements of these programs. We have therefore categorized the Broadcast Meteorology Concentration bachelor of science, the master of science in Broadcast Meteorology, and the Broadcast Meteorology Certificate as "MSU Broadcast," while the Professional Meteorology Concentration from MSU is classified as "Degreed."

Most profiles were straightforward to categorize, but some subjectivity was unavoidable. The profiles vary greatly in the degree of detail provided. Because of the broad range of programs offered by MSU, we generally followed a basic decision tree for profiles that included MSU. Those that included words such as certificate, certified, program, or broadcast were categorized as MSU Broadcast. All others were classified as Degreed as long as they included words such as degree, bachelor's, master's, or graduated. A few profiles indicated that they had "completed courses" or "done postgraduate work" from MSU. Since these profiles did not explicitly indicate that those individuals had completed a degree or certificate program, they were classified as Other. Most weathercasters were coded by the first author, with a handful of questionable cases being decided by consensus among the authors.

A few weathercasters minored in meteorology or had meteorological experience in the military. Even though these are vastly different paths, both are too qualified to be categorized as Other but not enough to be considered Degreed. Together, they account for only $2 \%$ of our data, so they were combined for simplicity.

To ensure an adequate cross section of weathercasters, we examined five groups of television markets across a range of market sizes. In each of these five groups, we evaluated all weathercasters listed on station websites. First, all weathercasters were evaluated at the ABC, CBS, FOX, and NBC affiliates in the five largest television markets, or designated market areas (DMAs), as determined by The Nielsen Company for the 2016-17 television season (Nielsen 2017). Eighty-nine weathercasters work at these 20 affiliates ("Top 5"), and the number of markets included in each of the five groups was chosen to keep the number of weathercasters as similar as possible. The second group was the "Million" markets, consisting of the six smallest DMAs with at least 1 million homes (DMAs 24-29). Similarly, the third group was the " $500 \mathrm{~K}$ " markets, consisting of the six smallest markets with at least 500,000 homes (DMAs 57-62). Nielsen identifies 210 DMAs overall, so the fourth group was the "Middle 10" markets (DMAs 101-110), in which each market has just under 300,000 homes. Many smaller markets have only one or two affiliates, so the final group was the "Bottom 26," consisting of DMAs 185-210. These five groups include a total of 447 weathercasters, 421 of which could be classified by our methodology. Figure 1 shows the locations of the 53 markets surveyed, which included a total of 127 affiliates. Weathercaster information was not available for the markets of Glendive, Montana; Juneau, Alaska; and Fairbanks, Alaska; therefore, those cities are not shown on the map.

After determining the education background of the weathercasters, the data were segmented in

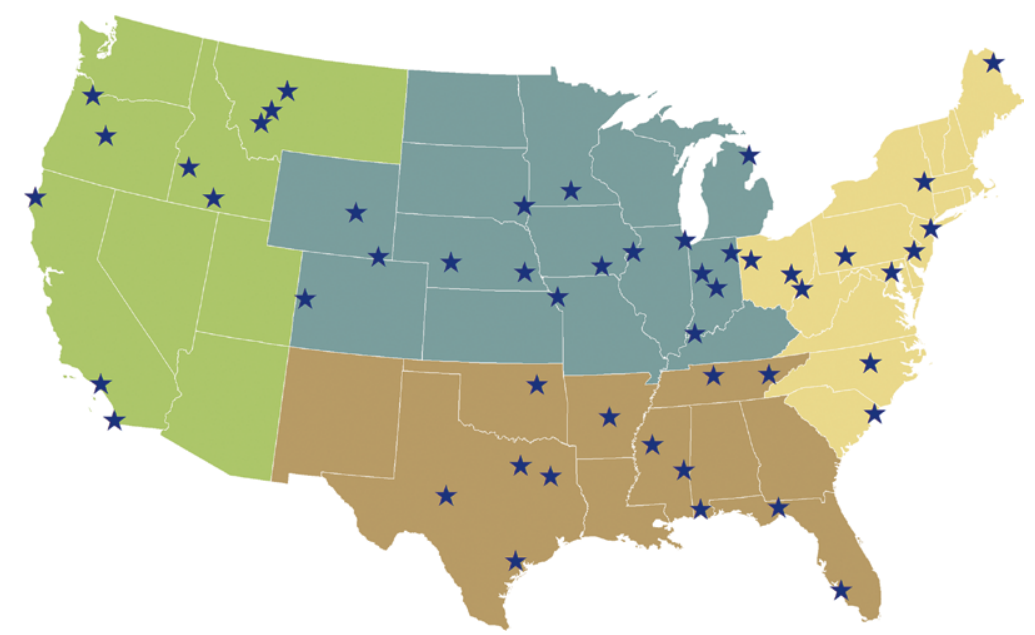

Fig. I. Map of the television markets included in the study. Shading of states represents the four NWS regions in the CONUS. 
various ways, including market size, gender, role (weeknights, mornings, or weekends), network affiliation, corporate ownership, and geographic region. The cumulative density function for a binomial distribution was used to evaluate whether the fractions in a given category were significantly different from the overall sample. Only those results that were significant at the 95\% level are shown here.

RESULTS. Of the 421-weathercaster sample set, $272(65 \%)$ had either a bachelor's or master's degree, 87 (21\%) were classified as MSU Broadcast, 10 (2\%) minored in meteorology or had military training, and $52(12 \%)$ were in the Other category (Fig. 2). These numbers are broadly consistent with past studies (Lazalier 1982; Wilson 2008; Maibach et al. 2017a,b; Cranford 2018). While variations in methodology likely color the numbers in each study, they paint a fairly consistent picture that between half and twothirds of weathercasters have a traditional meteorological degree and around one-fifth have broadcast meteorology training from MSU. The consistency in the results suggest that our smaller sample (421) is representative of the larger population $(2,040)$ sampled by Cranford.

Education levels varied somewhat when subdividing the dataset by television market size. The percentage of degreed meteorologists ranged from $58 \%$ to $70 \%$ (Fig. 3). The range was slightly larger for MSU weathercasters, from $14 \%$ to $29 \%$, with the highest in the Top 5 markets. Of the 10 minor/military weathercasters, 5 are from the Bottom 26. Finally, Other weathercasters range anywhere from $7 \%$ in the Top 5 to $17 \%$ in the Million markets.

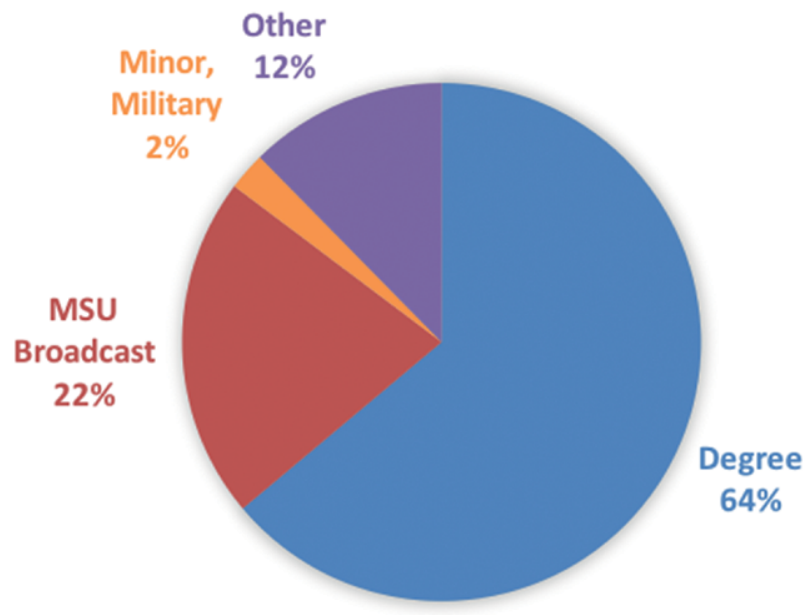

FIG. 2. Percentage of weathercasters with a given education level.
The original motivation for this study was a discussion between the authors about whether education levels were different between different television market sizes. However, after researching 53 of the 210 markets in the country, most variations by market size are not statistically significant at a high level. The highest $p$ value is related to the Top 5 markets having a higher percentage of MSU weathercasters, double the percentage of the Middle 10 and Bottom 26 markets. For Other weathercasters, biographies listed the field of study for 108 of the 149 people, and 95 of the 108 had a degree based in journalism and/ or mass communications. It is possible that many people with a journalism/communications degree chose to pursue MSU education and then become a weathercaster in a large market. It is also possible that some weathercasters were already in the profession but could not go back to school without quitting their job, so they decided to pursue an MSU distance option. At the same time, it should also be noted that the Top 5 markets have the smallest percentage of Other weathercasters of the five market sizes, so some level of meteorological knowledge remains a priority.

Geographical differences were examined by splitting markets based on National Weather Service (NWS) region. Education information for the weathercasters at the two Bottom 26 markets in the Alaska region was not available, so only the four continental United States (CONUS) regions were used. The education levels in markets in the western region were significantly different compared to the other three CONUS regions. Only $32 \%$ of weathercasters in the western region have a degree compared to $69 \%-75 \%$ in the other three regions (Fig. 4). The western region also had many more MSU weathercasters (39\%) compared to $12 \%-19 \%$ in the other three regions. Finally, 29\% of the western region weathercasters are Other compared to $8 \%-11 \%$ from the other three regions. It should also be noted that the western region was represented by only 77 weathercasters compared to $99-140$ in the other three regions, although those 77 weathercasters do represent 11 of the 53 television markets. By chance, three of the western region markets were Bottom 26 markets in the state of Montana. These three markets actually had a higher number of degreed weathercasters (four out of six), so they did not significantly skew the regions' results.

Interestingly, education levels did not change much for different roles at the station. Weathercasters were divided into four groups: weeknight, morning, weekend, and all other positions (the fourth, 


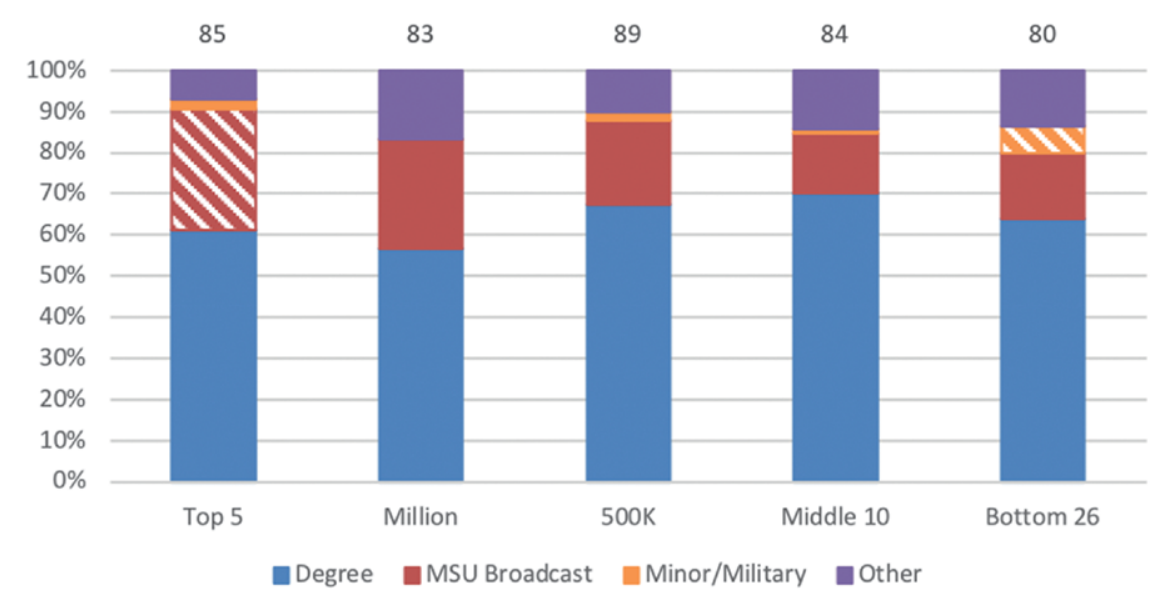

FIG. 3. Percentage of weathercasters with a given education level, broken down by market size. White diagonal lines indicates fractions significantly above the population at the $95 \%$ level. Numbers indicate the number of weathercasters in each market subsample.

fifth, and sixth weathercasters at larger stations). None of these subsets had significant variations. We also examined variations between affiliates of the four major networks (ABC, CBS, FOX, and $\mathrm{NBC})$ and did not find any significant differences (not shown).

The differences in education level were a bit more distinct based on ownership. The 127 individual stations are owned by 42 different companies. ${ }^{1}$ Of the 42 different companies, 9 own at least five stations. Those nine companies were examined in further detail. Sinclair Broadcast Group and CBS employed $41 \%$ and $48 \%$ degreed meteorologists, respectively (Fig. 5). The two companies also employed the highest percentage of MSU weathercasters at 39\% each. In addition, Sinclair had the highest percentage of Other weathercasters at $20 \%$. By comparison, Nexstar Media Group had the highest percentage of degreed meteorologists $(87 \%)$, the lowest percentage of MSU weathercasters (9\%), and the lowest percentage of Other weathercasters (2\%).

\footnotetext{
${ }^{1}$ Since the data were collected, Gray Television purchased Raycom Media and Nexstar Media Group announced plans to acquire Tribune Media.
}

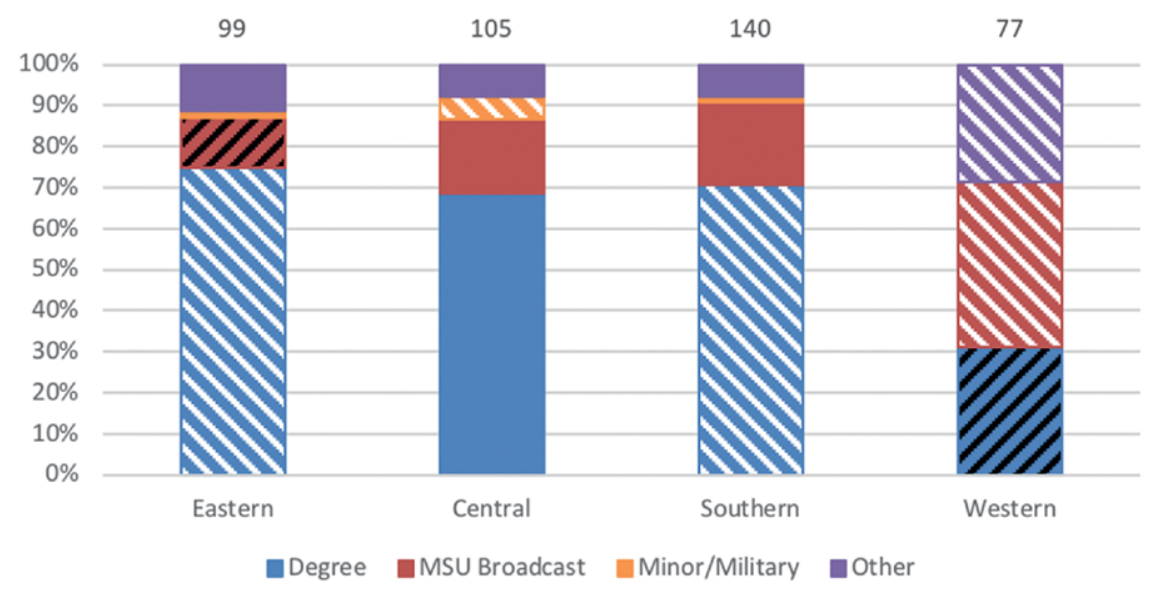

FIG. 4. As in Fig. 3, but for geographic region. White diagonal lines indicates fractions significantly above those in the overall population at the $95 \%$ level. Black diagonal lines indicate fractions significantly below those in the overall population. 


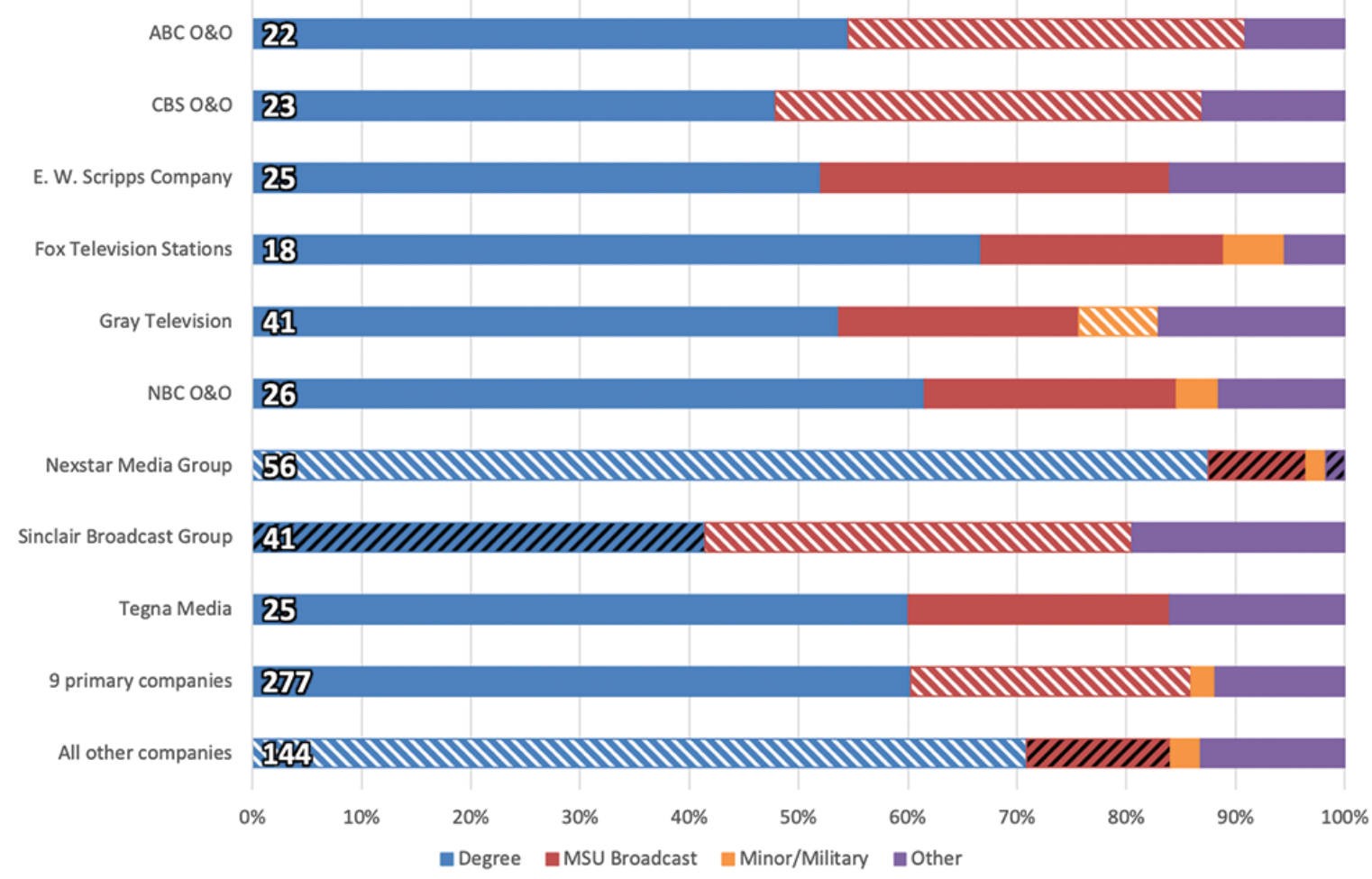

Fig. 5. As in Fig. 4, but for station ownership group. The number embedded on the left side of the bar indicates the number of weathercasters employed by a given station ownership group.

would prioritize different qualifications. These results verify that to be the case.

Men represented exactly two-thirds of the dataset. Among men, 69\% had their degree as opposed to just $55 \%$ of women (Fig. 6). While the difference in MSU and minor/military is very small between the two genders, $21 \%$ of women are Other as compared to just $8 \%$ of men.

Of the 127 stations, 12 stations do not have any degreed meteorologists. These stations have staffing that ranges from one to four weathercasters and span each of the five market sizes studied. In total, 32 stations are fully staffed by degreed meteorologists. They have staffing that ranges from one to six weathercasters, and they span each of the five market sizes studied.

DISCUSSION. The statistically significant differences between men and women are some of the largest in the study. The history of gender in broadcast weather is complex and continues to be predominantly male, despite an earlier period when the majority of weathercasters were women. It has long had elements of systemic sexism: for many years, female weathercasters were often hired based on their physical appearance rather than their education background (Henson 2010; Turner 2010). Studies have also shown that holders of professional credentials such as the AMS Seal of Approval or the AMS Certified Broadcast

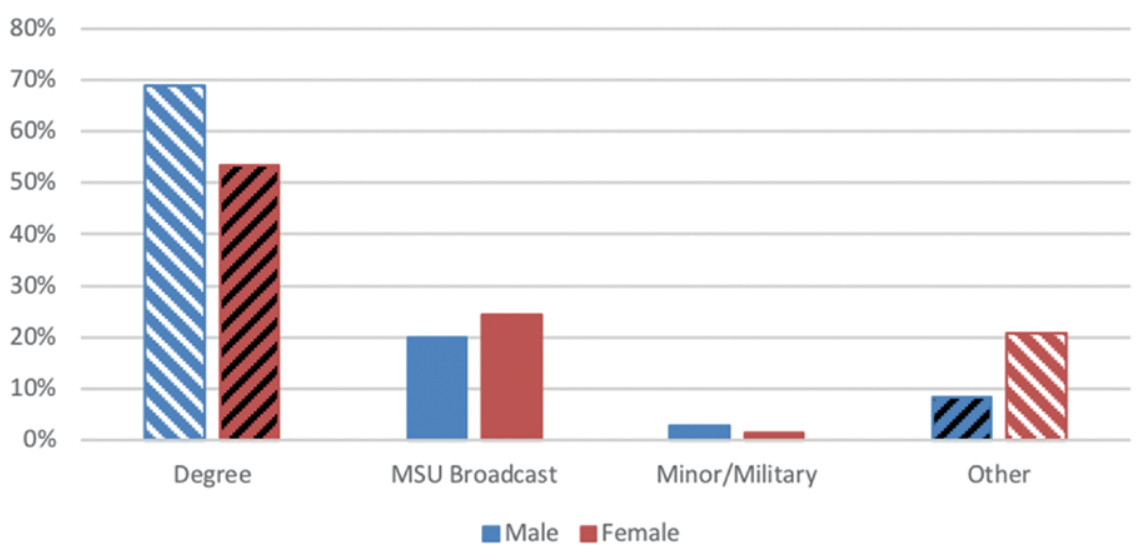

FIG. 6. As in Fig. 4, but for gender. 
Meteorologist designation are disproportionately male (e.g., Wilson 2008). Cranford (2018) showed a smaller but still statistically significant difference between the percentage of men and women with degrees. Regardless of the reasons, these results suggest we have not achieved gender equality.

We invested a lot of time deciphering the biographies to determine the education level for each weathercaster. This was due in part to the wide variations in how these biographies were written. Those profiles that listed a specific degree or certificate in a specific field of study from a given university-such as "MS in broadcast meteorology from Mississippi State" or "BS in meteorology from Penn State" were the most straightforward to classify. In some cases, the broad range of programs offered by MSU required a more nuanced approach to ensure we accurately categorized those biographies. Those stating they had attended a university but were not as direct in stating the field of study or what degree or certificate was earned, if any, we classified as "Other."

It is beyond the scope of the paper to determine the causes or reasoning for many of the differences found in this paper. We cannot truly know the reasons for differences by region, television market size, and television station ownership without a full census of general managers and ownership at the different television stations. However, the prevalence of MSU Broadcast is likely because of the option for distance education as well as the differing requirements of the various programs MSU offers. Both of these factors allow for greater access than other meteorology programs.

The Pennsylvania State University (PSU), Florida State University (FSU), and the University of Oklahoma (OU) are traditionally three of the largest meteorology programs in the country. However, in this dataset, these three schools finished second, third, and fourth, respectively, in the number of weathercasters graduating from any university (Fig. 7). Mississippi State University graduated the largest number of degree-holding weathercasters, even when including only those with either a professional bachelor's or master's degree. In total, 34 weathercasters hold such a degree, in addition to the 87 who were listed as receiving a broadcast degree or certification. Those numbers combine to give $29 \%$ of the dataset some affiliation to MSU, as much as the next six largest schools combined (Fig. 7). Another way of viewing the data is that the MSU Broadcast program alone has nearly as many graduates as the four largest traditional programs (MSU degreed, PSU, FSU, $\mathrm{OU})$ combined in our sample. These results show the prevalence of the Mississippi State University meteorology program, especially the Broadcast Meteorology program.

This paper and those of Cranford (2018) and Maibach et al. $(2017 a, b)$ represent only the first steps to understanding the evolving workforce in broadcast meteorology. Many questions have been left to future studies. Are the number of graduate degrees growing in the broadcasting sector as they are in so many other sectors of our field? Much attention has been given to weathercasters (Lazalier 1982; Wilson 2008; Maibach et al. 2017a,b; Cranford 2018) and university faculty (MacPhee and Canetto 2014), but what does the workforce look like among the growing number of nonbroadcast private sector meteorologists? Finally, what are the relative numbers of weathercasters holding an AMS CBM versus seals from either AMS or the National Weather Association (NWA)? The defining difference between the new AMS CBM and the old AMS Seal of Approval is the requirement for a degree in meteorology that includes advanced calculus and dynamics. However, many seal holders were grandfathered into the new CBM, so it is not a proxy for education background on its own. At present, about two-thirds of weathercasters have degrees that meet CBM standards. Only time will tell

FIG. 7. Number of weathercasters graduating from universities in the top 10 of the sample. MSU number includes graduates with either professional bachelor's or master's degrees.

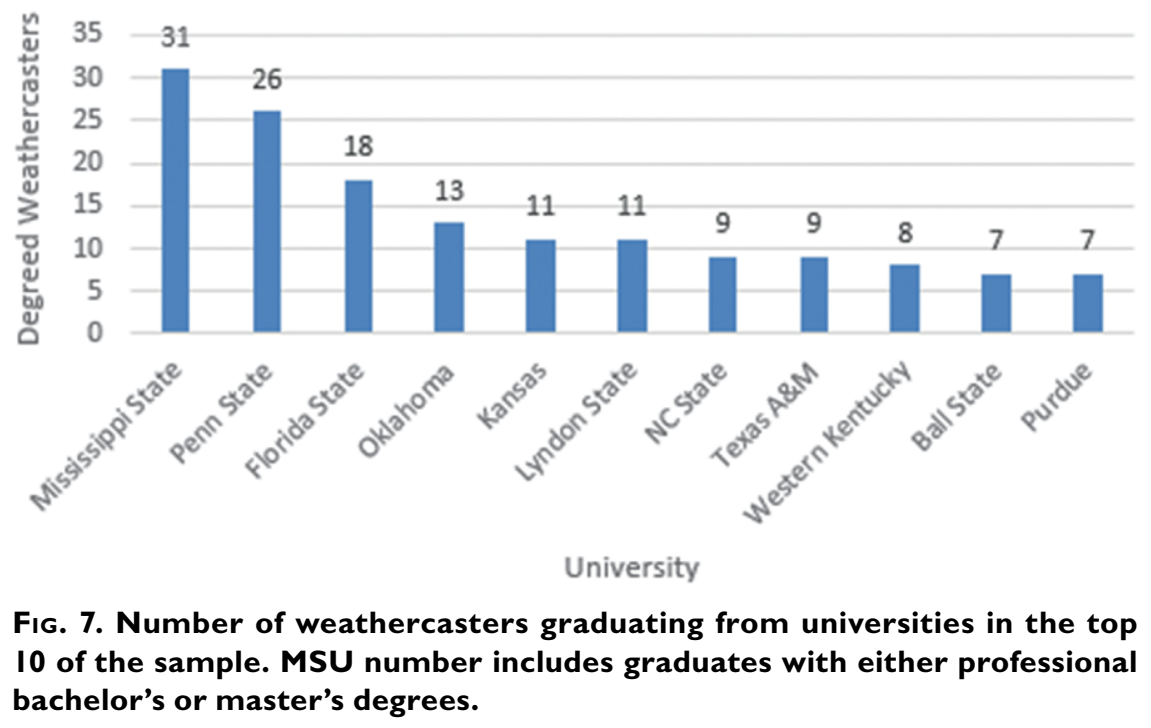


how effective the CBM is at promoting these types of degrees and maintaining the scientific standards of the on-air weathercasters.

\section{REFERENCES}

Cranford, A., 2018: Women weathercasters: Their positions, education, and presence in local TV. Bull. Amer. Meteor. Soc., 99, 281-288, https://doi .org/10.1175/BAMS-D-16-0317.1.

Henson, R., 2010: Weather on the Air: A History of Broadcast Meteorology. Amer. Meteor. Soc., 241 pp.

Knox, J., 2008: Recent and future trends in U.S. undergraduate meteorology enrollments, degree recipients, and employment opportunities. Bull. Amer. Meteor. Soc., 89, 873-883, https://doi .org/10.1175/2008BAMS2375.1.

Lazalier, J., 1982: A report on the results of a television weather survey. Natl. Wea. Dig., 7 (2), 5-9.

MacPhee, D., and S. S. Canetto, 2014: Women in academic atmospheric sciences. Bull. Amer. Meteor. Soc., 95, 59-67, https://doi.org/10.1175/BAMS-D-12-00215.1.

Maibach, E., D. Perkins, K. Timm, T. Myers, B. Woods Placky, S. Sublette, A. Engblom, and K. Seitter, 2017a: A 2017 national survey of broadcast meteorologists: Initial findings. George Mason University Center for Climate Change Communication, 75 pp., www .climatechangecommunication.org/wp-content /uploads/2017/03/2017WeathercasterSurveyReport .pdf.

— of climate change appear to be rapidly evolving. Bull. Amer. Meteor. Soc., 98, 2061-2064, https://doi .org/10.1175/BAMS-D-15-00206.1.

Nielsen, 2017: Local television market universe estimates. 6 pp., www.nielsen.com/content/dam/corporate/us /en/docs/solutions/measurement/television/2016 -2017-nielsen-local-dma-ranks.pdf.

Turner, R., 2010: Weather heights: The emergence of aeronautical meteorology as an infrastructural science. Ph.D. dissertation, University of Pennsylvania, 255 pp., http://repository.upenn.edu /edissertations/147/.

Wilson, K., 2008: Television weathercasters as potentially prominent science communicators. Public Understanding Sci., 17, 73-87, https://doi .org/10.1177/0963662506065557.

World Meteorological Organization, 2015: Meteorology. Vol. 1, Guide to the implementation of education and training standards in meteorology and hydrology, WMO/TD-1083, 40 pp., https://library.wmo.int /pmb_ged/wmo_1083_en.pdf.

\section{"A thoughtful analysis of actions that we need to take to reduce the impacts of extreme weather... a must-read for everyone with an interest in the weather and climate." \\ - FRANKLIN W. NUTTER, \\ President, Reinsurance Association of America}

\section{Living on the Real World: How Thinking and Acting Like Meteorologists Will Help Save the Planet}

WILLIAM H. HOOKE

Meteorologists sift through a deluge of information to make predictions every day. Instead of being overwhelmed by the data and possibilities, they focus on small bits of information while using frequent collaboration to make decisions. With climate change a reality, William H. Hooke suggests we look to the way meteorologists operate as a model for how we can solve the twenty-first century's most urgent environmental problems.

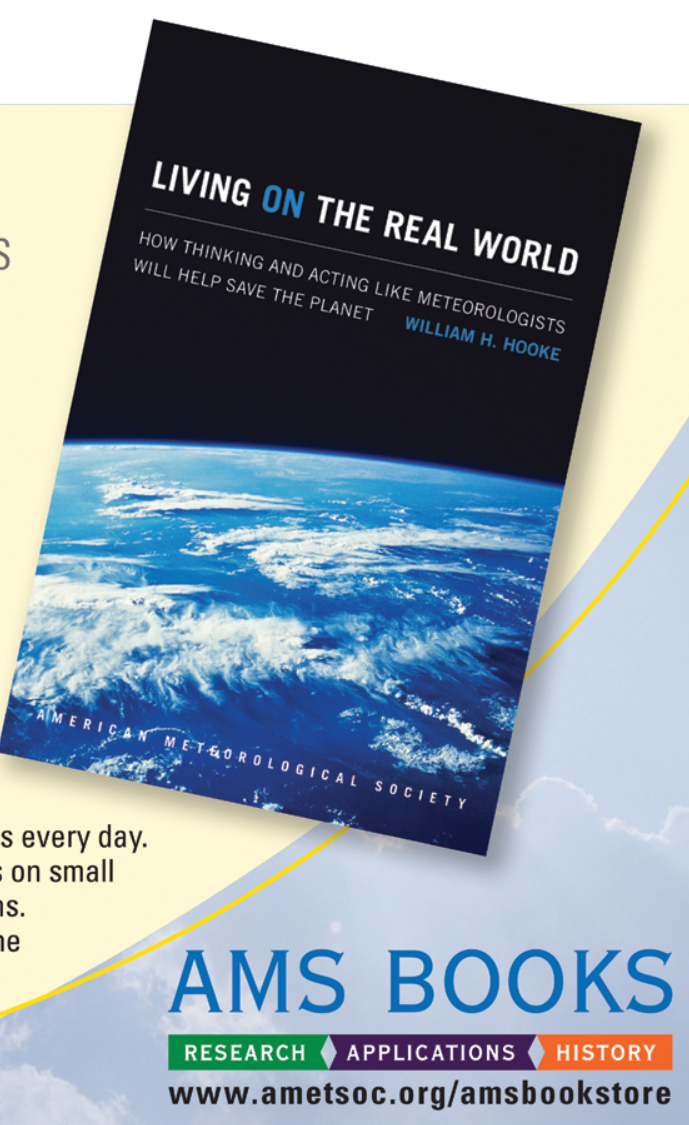

